\title{
Corporate real estate management during the transition in Russia*
}

\author{
Richard Grover, Mikhail Soloview, Vladimir, Zakharchenko**
}

The article reviews corporate real estate management problems during the transitional period of the Russian society between 1991 and the present time. There are interconnected processes of forming and developing the market legislative base for a real estate market, corporative structures, and real estate management. It illustrates the strategic and operational interaction between the corporation management system and its real estate subsystem, and the functions of the corporate real estate department and managers in the top management of corporations, showing the importance of good quality information about real estate assets. Imbalance between the three results in serious problems and these have been a feature of the corporative development during this period.

Der Artikel berichtet über die Probleme bei der Immobilienverwaltung von Firmen in Russland von 1991 bis heute. Es gibt Zusammenhänge zwischen der sich entwickelnden Gesetzgebung für den Immobilienmarkt, den gesellschaftlichen Strukturen und dem Immobilienmanagement. Der Artikel erklärt die strategischen und operativen Interaktionen zwischen dem Management-System der Firmen, ihrem Immobilienmanagement-Teilsystem, den Funktionen der Immobilienabteilung und den Managern der Unternehmensleitung und zeigt die Wichtigkeit von qualitativ hochwertigen Informationen über den Immobilienbesitz. Ein Ungleichgewicht zwischen der Entwicklung der Gesetzgebung, den Unternehmensstrukturen und dem Immobilienmanagement führt zu ernsthaften Problemen, welche eine Besonderheit für die Firmenentwicklung in Russland während dieser Periode waren.

Key words: transition period, corporate development, legislative base, real estate management

\footnotetext{
Manuscript received: 28.06.05, accepted: 27.02 .07 (3 revisions)

** Richard Grover, Assistant, Oxford Brookes University. Main research areas: Real estate management, European Union accession and teneure. Corresponding address: rgrover@brookes.ac.uk

Mikhail Solovew, Prof., Higher School of Economics. Main research areas: Valuation and real estate management.

Vladimir Zakharchenko, Manager (Gazprom) and Ass. Prof., School of Privatisation and Entrepreneurship. Main research areas: Management of corperate rael estate and land issues.
} 


\section{Introduction}

During the last decade world research and practical analysis has shown a growth of interest in the corporate real estate management (CREM) problems. Corporate real estate is a large-scale multi-component complex. For different branches of business it includes combinations of single and complex objects, such as land and forest sites, mines, water objects, separate buildings and constructions, and unified technology and administrative complexes. Real estate objects and complexes form the property foundation for corporations. Real estate provides living and working spaces for corporations and their personnel engaged in administrative and operational activities. The CREM includes tactical and strategic programmes and plans, operational decisions, the trading of assets, property contracts, investment, and the development projects with the immovable objects and complexes in order to provide efficient ways of achieving corporate strategic targets and efficient solutions to tactical and operational tasks of corporations.

Interest in CREM is concerned with different questions. Works by Joroff (1994), Weatherhead (1997) and O'Mara (1997, 1999) helped to define the role and place of corporate real estate as one of the key resources for business strategic management. A number of researchers have considered the interconnection between the corporate mission and purpose and real estate management, for example, McGregor (2000), Yontz (2001), Osgood (2004), and Acoba/Foster (2003). Case studies of the interconnection between these were published by senior real estate managers of multinational corporations, such as United Technologies Corporation (Zappile 2004), SBC Communication (Wagner et al. 2003), and large-scale organisations in the social sector, for example, see the works of Baldry et al. (1999) for the higher education and health systems. The papers of Pfnuer et al. (2003, 2004) and Stoy/Kytzia (2004) illustrate the peculiarities of strategic real estate aspects in continental European conditions and Ho (2000) in the Asia Pacific region.

Another conceptual way has been to see the corporate real estate as part of a complex service structure. Cotts (1999) and McNamara (2003) emphasised the integrative character of real estate management and included corporate real estate as a basic component of facility management systems, which should be a major responsibility of specialist senior managers. The facility management concept was defined as the integration of corporate objectives, personnel management, and business space. The integration was presented as different regulated components by Nutt (2000). Real estate has also been defined as a multi-faceted object for management. Avis/Gibson (1995) interpret real estate as a complex object for management through the following three components: physical, financial and functional. Gibson (2000) elaborates this concept for flexibly providing strategic immovable resources. Sustainable and efficient real estate development and environmentally sustainable workspaces are the main 
subjects for research by Kincaid (2000), McGregor (2000), and Keeping/Shiers (2003). O'Mara et al. (2002) analyses the global function of real estate for large corporations. A major theme for research has been to present new mechanisms and models for corporate real estate management. These include sale and leaseback (Devaney/Lizieri 2004), (Bryan 2003), outsourcing (Lyons 2001), benchmarking (Ho et al. 2000), real estate partnerships (Asson 2002), and risk management and portfolio construction (Hudson-Wilson/Wurtzebach 1998). One of the basic roles of real estate is to be a guarantee for financial credits. Real estate's potential for efficient investment has stimulated a wide spectre of research in real estate valuation. This includes fundamental methodical issues, for example, Scarrett (1991), analysis of valuation accuracy by Crosby (2000), and approved valuation standards at international and European level by the International Valuation Standards Committee (IVSC 2003) and The European Group of Valuers' Associations (TEGoVA 2000). Grover/Soloviev (2001) undertook a comparative analysis of the valuation professional standards in the national and international context. Changes in the area of professional standards, such as valuation standards and in the harmonization of valuation and financial reporting standards, have been areas of discussion (Cooke, 2004). High quality real estate valuation is needed as a reliable basis for efficient corporate real estate management. The integrative character of real estate management efficiency has been the subject of investigations. Here research mainly follows the understanding of problems similar to the balanced scorecard concept of Kaplan/Norton (1996) with real estate adaptations. Among the works are conceptual discussions by Lubieniecki and Desrocher (2003) about efficiency and effectiveness and Baldry (1999) about the NHS Community Health Trust. Hill (2001) shows the value of real estate in determining shareholder income. There are interpretations of real estate management as a business process, such as Kops (2003), and as a business continuity, such as Msezane and McBride (2002).

Real estate management plays an important role in the market reforms of countries with transitional economies. Some of the problems encountered in developing functioning real estate markets in transitional economies are discussed in Grover et al. (2000) and Grover (2006). Real estate market formation and the successful advance of trading in privately owned land and property interests has become one of the most remarkable signs of market economy formation and development. A new impulse has taken place in Russia for the real estate management problem concerned with large-scale corporate formation and development. The stimulus came from the practical needs of leading corporations in current transitional conditions and needs of the efficient CREM. Today the corporations have become very important for the national and regional economic growth, the development of competitive businesses, and strategic reconstructions. Corporate real estate resources are one of the key areas for corporate reforms and development. Here the aforementioned Western 
researches and advanced experience can provide useful orientation and high potential for adaptation by Russian (and other transitional economies) researchers, corporate leaders and executive real estate managers. Over recent years there have been a number of publications that examine comparable real estate problems and interpret these for Russian conditions including Maximov (2000, 2003), Grabovy (2001), and Grover/Soloviev (1997, 2001). Since 2000 there have appeared a number of specialised real estate departments in large Russian organisations, such as fuel and energy companies, state and municipal executive bodies, and financial institutions.

\section{Aims of the paper}

The paper's purposes are to define the reasons for and ways of solving the CREM problem in the Russian transitional economy. The investigation is concentrated around a conceptual model of the corporate management system (CMS) and its interaction with its CREM subsystem. Analytical accents are on the dynamics of leading corporations formation and development, legislative provision for the formation and development of a real estate market and real estate management, and the adaptation and implementation of the main concepts and principles of the CREM creation. The analysis is useful both for the transitional economies' corporations and their Western stakeholders. It is necessary for better understanding, for creating new and/or transforming existing CREM subsystems, for efficient interaction with the CMS, and in meeting corporate purposes and tasks.

The processes of corporate development, the development of the real estate legislative base, and corporate real estate development needed to occur in parallel. From time to time during Russia's transition the processes of economic development and reorganisation moved ahead of legislation. Sometimes enacted legislation did not work well in practice and had to be corrected, for example in bankruptcy and mortgage. The cost of disharmony took the form of a great deal of subsequent confirming of procedures and re-processing masses of documents and databases, the alteration of property rights, changes to previously-made decisions, and the refusal to recognise previously agreed trades in assets. The detailed analysis of the transition processes can be useful for understanding the reasons for the problems now being encountered and to find efficient ways of solving them. Russian corporate bodies are, to an extent, prisoners of their own recent histories and of the problems the federal government has faced in developing real estate polices and getting its legislation approved. They had no prior experience when working at the solutions to CREM problems. 
Figure 1. Central corporation management system and subsystems interaction

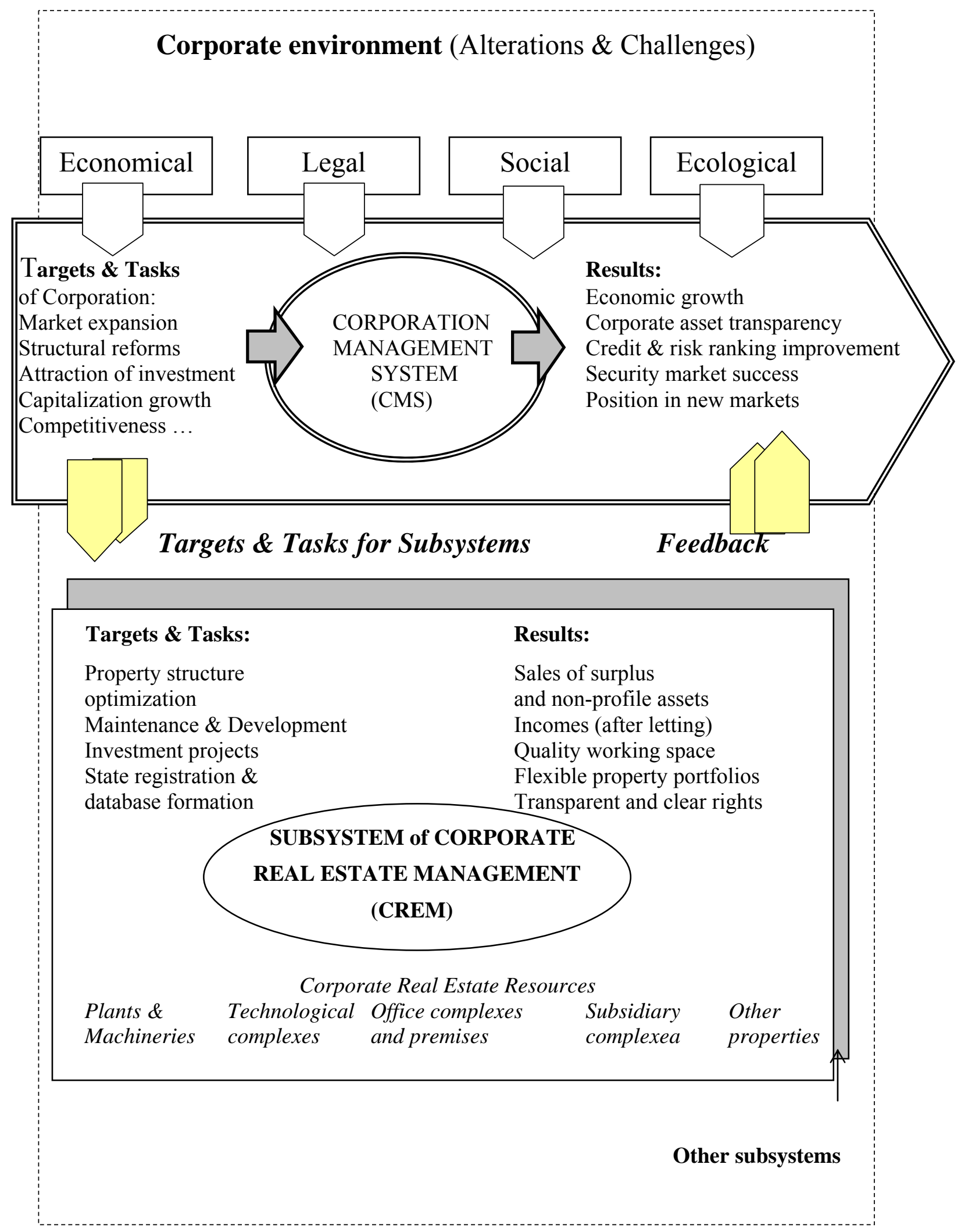


Figure 2. Functions of Corporate Real Estate managers and their interaction with Corporation Management System
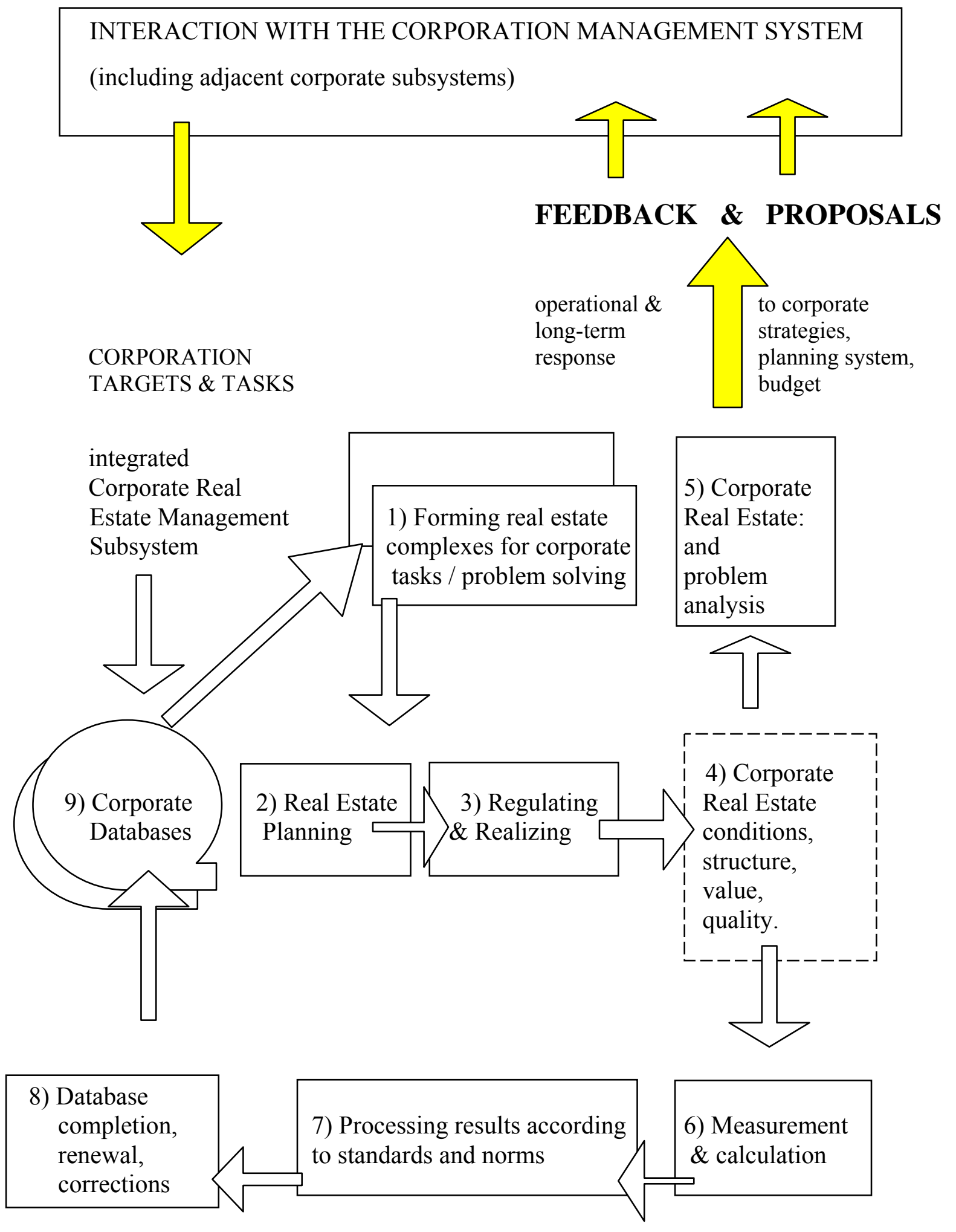


\section{Model of the contemporary CREM}

To summarize the aforementioned Western experience and the Russian advances in corporate real estate (Soloviev/Zakhartchenko 2004, 2005), the modern CREM subsystem concept and its interaction with the CMS can be summarized in Figures 1 and 2. The corporate purposes and strategies are connected with the dynamic processes of corporate competitive growth, the most economical provisions, new market advances, and so on. Corporate real estate is one of the most important resources. The CREM targets and tasks strictly follow the targets and tasks of the corporation as a whole, and their fulfilment helps to provide for planned corporate development. Failure to achieve explicit and implicit CREM targets and tasks can have serious implications for corporate efficiency through the disruption of other parts of the corporation or, at least, the reduction in their efficiency or productivity.

Figure 1 shows that the results of the CREM are a necessary feedback for successful corporate governance. The corporate environment has a complex character and influences both the central corporation management system and its functional and infrastructural subsystems, such as the real estate management. In addition Figure 1 shows the plural internal structure of the real estate subsystem, including different kinds of real estate objects, such as technological and administrative complexes, plant and machinery, and separate buildings and constructions.

Figure 2 details the functions of the CREM subsystem and corresponding real estate management activities, and their interaction with the CMS as a central general system. The functional content and interconnections create typical concrete sub-systems. The CREM subsystem has a number of specific properties. For example, different corporate activities and problem solving can be connected with different real estate complexes. Alterations of the real estate list and properties must be fixed in the state registers. The registration procedures are rather complicated and durable. Results of the real estate alterations can influence current and future company value. That is why the CREM subsystem has two feedback mechanisms. The first is an internal one in response to the tasks given to it by the central system in solving and formulating results for real estate management. Processing is necessary in order to complete and correct the real estate part of the full corporate database. The second feedback of the Figure 2 is an external one, mentioned in Figure 1, and directed towards the central corporation management system. This second feedback reflects the responses of real estate management during the process of formulating targets and problem solving. Also the external feedback has another information flow. These are proposals to the central system for strategy, plans, budgets, and the support of other parts. Both information flows of the second feedback are based on analysis. The analysis must include both operational results of management and a general appraisal of corporate real estate conditions 
and characteristics. Thus the CREM subsystem creation is a complex and complicated process. It demands experience and deep understanding the CMS problems and their interconnections with real estate both in operative and strategic decision making.

It is important to note, that the majority of strategic management monographs overlook the real estate problem. They therefore tend to neglect the most valuable resource in an organization's balance sheet and one whose efficiency problems can have serious repercussions for the organization as a whole. This may be because real estate management requires some specific skills and competences that are not normally part of management education, for example, the management of three-dimensional space. Of course, real estate has special characteristics, which are the concerns of specialists, as well as having a particular role in the transition process. Real estate problems have increasing significance in the global development of corporate management, and Western research reflects this tendency. Corporate collapses, in which asset values turn out to be less than anticipated, also point to the need to give proper attention to real estate issues (Allen/Gale 2000; Pomerleano 2001; Herring/Wachter 2002).

\section{The situation at the start of the transition period}

There are different processes which reflect the features of the transition period. The intensive formation of a real estate legislative base, necessitated by the creation of a private property market and the transfer of ownership of many parcels of real estate from the public to the private sector, and the development of corporate structures are amongst the most representative processes. The first of them is necessary for the formation of open market institutions. The second one in Russia has been particularly concerned with the fuel and energy companies and is significant for the national economy's condition and its competitiveness in the world market.

Privatization after 1991 was the main mechanism in the formation of private property markets. There has been the rapid privatization of a large quantity of undertakings. The process was a multi-stage one. The first "voucher" stage and the following stages of "monetary" and "cellular" privatisation have resulted in the principal alterations of the Russian economic structure. In the mid 1990s the public sector ended its monopoly leadership. The major corporations were formed at the start privatisation process from former state concerns. CREM problems were not priorities of the privatisation process.

The following were the most important characteristics of CREM at the start of the transition process.

1. In the beginning of the 1990s reforms in Russia there was an absence of a real estate legislative base. Market experience was similarly largely absent. What existed was not orientated towards the requirements of a market economy. 
Similarly, the juridical processes needed for the efficient functioning of a property market were not developed in areas such as the recognition of private property rights, land registration, bankruptcy, mortgages, investment activity, and company creation and reorganisation.

2. There was an absence of land or real estate registers, cadastres or similar reliable databases for the privatised real estate objects that accurately recorded property rights and parcel boundaries (although technical inventorisation existed mainly for residential buildings and premises). The large-scale and multi-unit state assets transmitted to the newly created joint-stock companies needed detailed and precise description and valuation. A special problem concerned the ownership of the land on which privatised undertakings stood as distinct from the buildings themselves. The absence of real estate database had a strongly influence on CREM and was responsible for many of the questions as to whether there was proper process in the privatization and whether the transfer of ownership took place at fair value.

3. Classifications and definitions of corporate real estate objects were absent. Should they be separate units or technological and administrative complexes? Should plants be viewed as integrated technological complexes or separate technological lines available as individual units for investment projects and future trading? The answers to the questions were important for corporations' investment activity, and the legal and reliable use of real estate objects in future market operations, for secured borrowing, and for efficient CREM systems.

4. The majority of privatized industrial concerns had many social and communal assets with a replacement value of hundreds millions of dollars. The urban areas were often "company" towns. However the real estate objectives that led to them being part of industry's assets were obsolete and not suited to a market economy. They dated from an era when state budgets for industrial development also included funding for housing for workers and social infrastructure, such as educational and health care facilities. It was one of the transitions from a social economy mechanism into a market one in which there is a clear demarcation between the responsibilities of private industry and the state. It was not helped by hasty privatization. Before the transition, state enterprises were the main vehicles for urban development and the on-going maintenance of social and communal objects. Complexes of residential and social buildings, that had been developed and were maintained by industrial enterprises, formed the built environment infrastructure for their towns. But in order to permit privatization, social assets had to be transferred to local authorities, and local authorities needed a financial base to be able to maintain them.

5. One of the serious initial problems was connected with the so-called nonprofile assets, and these problems increased over time. There was an absence of any rational real estate strategic policy for the privatized former state concerns. The absence of a real estate strategy could have negative tendencies, in 
particular, for natural monopolies, such as energy companies. The monopolies could, and did after privatization, continue the policy of step by step decrease in the quality and value of their corporate assets structure and efficiency of the CREM.

It is important to look the problematic evolution of CREM during the period of reforms after 1991, and to analyse the reasons, tendencies, and perspectives for contemporary CREM efficiency.

\section{The Dynamic of the Transitional Period in Russia: A comparative analysis}

Table 1 provides a visual outline of some of the characteristics of the transition period. GDP and investment data illustrate deep and unchanging economic stagnation until the trough of 1997-1998 and a slow recovery from crisis since 1999. The privatization data shows a qualitative transition from a mass voucher process to financial and cellular privatisation. The real estate market data is useful in understanding market dynamics. The market did not emerge at the beginning of the reforms, but was created step by step for different sectors. The market's risk characteristics can be identified through yield data, and they were strongly influenced by the financial crisis of 1998. The spread of prime property yields, taken from the journal EuroProperty, has narrowed in relation to those in Western Europe but yields remain higher than for the Western European capitals, which tend to be in the range of $5 \%$ to $8 \%$. The central place in Table 1 belongs to legislation to do with corporations and real estate market which can be compared with the general economy and real estate market dynamics.

The Russian social and economical transition between 1991 and the present time can be divided into following stages.

1991-1994. These years saw the start of both social and economical reforms, mass privatisation through vouchers, and the constitutional basis for private property and market regulation, as well as the formation of structures for corporations. However, the roots of future real estate problems can be traced back to this period.

1995-1996. This period saw the development of the financial basis for privatisation, a search for new mechanisms for privatisation, the first corporate expansions and strategic partnerships, and advances in the listing of corporations in the stock exchanges of Russia and abroad.

1997-1998. During this period there was intensive development of the real estate legislative base and of corporate activities, the creation of cellular privatisation, but a crisis in the financial and economic system. 
1999-2000. This was the immediate post-crisis period in which the economic dynamic slowed down, but there was the beginning of recovery in economic growth.

2001 to the present time. This period has seen intensive growth and some solutions to the CREM problems.

Table 1. Comparative dynamic of the transitional period

\begin{tabular}{|c|c|c|c|c|c|c|c|c|c|c|c|c|c|c|}
\hline Year & 1991 & 1992 & 1993 & 1994 & 1995 & 1996 & 1997 & 1998 & 1999 & 2000 & 2001 & 2002 & 2003 & 2004 \\
\hline \multicolumn{15}{|c|}{ General Economic Data } \\
\hline $\begin{array}{l}\text { GDP } \\
\% \text { of.year }\end{array}$ & 89.9 & 82.9 & 89.5 & 86.8 & 99.3 & 95.4 & 101 & 96.5 & 106.1 & 109.3 & 104.4 & 102. & 107.5 & 107 \\
\hline $\begin{array}{l}\text { Investment } \\
\% \text { of pre- } \\
\text { vious year }\end{array}$ & 85.0 & 60.3 & 88.0 & 75.7 & 89.9 & 82.0 & 95.0 & 88.0 & 105.3 & 117.4 & 108.7 & 102 & 112 & 136.4 \\
\hline \multicolumn{15}{|c|}{ Legislative Approval } \\
\hline \begin{tabular}{|lr|}
\multicolumn{2}{|l|}{ Civil Code } \\
(parts & 1 \\
and 2) & \\
\end{tabular} & & & & * & $*$ & & & & & & & & & \\
\hline $\begin{array}{l}\text { Land Code } \\
\text { /connected } \\
\text { laws }\end{array}$ & & & & & & & & & & & $*$ & & & \\
\hline $\begin{array}{l}\text { Joint- } \\
\text { Stock } \quad \text { Co }\end{array}$ & & & & & $*$ & & & & & & & & & \\
\hline & & & & & & & & & & & & & & \\
\hline $\begin{array}{l}\text { State } \\
\text { Regis- } \\
\text { tering Act }\end{array}$ & & & & & & & $*$ & & & & & & & \\
\hline \multicolumn{15}{|c|}{ Corporate Sector } \\
\hline $\begin{array}{l}\text { Privatisa- } \\
\text { tion } \\
\text { (types): }\end{array}$ & & & & & & & & & & & & & & \\
\hline $\begin{array}{l}\text { Voucher } \\
\text { privatisatio } \\
\text { n }\end{array}$ & & & & & & & & & & & & & & \\
\hline $\begin{array}{l}\text { Financial } \\
\text { privatisa- } \\
\text { tion }\end{array}$ & & & & & & & & & & & & & & \\
\hline $\begin{array}{l}\text { Cellular } \\
\text { privatisa- } \\
\text { tion (incl. } \\
\text { state sha- } \\
\text { res sales) }\end{array}$ & & & & & & & & & & & & - & & $\rightarrow$ \\
\hline $\begin{array}{l}\text { Oil-gas } \\
\text { inint }\end{array}$ & & & & $*$ & * & & & & & & & & & \\
\hline $\begin{array}{l}\text { co } \\
\text { formation }\end{array}$ & & & & & & & & & & & & & & \\
\hline $\begin{array}{l}\text { Start of } \\
\text { security } \\
\text { market } \\
\text { listing }\end{array}$ & & & & & & * & & & & & & & & \\
\hline
\end{tabular}




\begin{tabular}{|l|l|l|l|l|l|l|}
\hline $\begin{array}{l}\text { Corp. } \\
\text { Code } \\
\text { (ethic) } \\
\text { approval }\end{array}$ & & & & & \\
\hline \multicolumn{2}{|l|}{ Real Estate Market } & & \\
\hline $\begin{array}{l}\text { Start for } \\
\text { Moscow } \\
\text { data } \\
\text { recognizati } \\
\text { on in the } \\
\text { European } \\
\text { statistics }\end{array}$ & $*$ & $*$ & & & & \\
\hline $\begin{array}{l}\text { Yield for } \\
\text { the } \\
\text { Moscow } \\
\text { office } \\
\text { market, \%) }\end{array}$ & $15-20$ & $15-22$ & $22-25$ & $19-22$ & $13-15$ \\
\hline
\end{tabular}

The analysis of the changes in Russian CREM during the transition period is presented under the following headings.

- Evolution of the legal and market environment. This examines the changing legislation concerned with the regulation of real estate management and corporate governance and basic market mechanisms. The information is taken from Russian Federation legislative databases, such as the "Consultant+".

- Events and problems on the corporate and CREM front. This identifies important events in corporate life and focuses on the large corporations of the fuel-energy sector. The information is taken from the internet-sites of these companies, such as www.gasprom.ru. Commentaries on CREM try to show fundamental sources and tendencies of the problems (1)-(5) identified above.

\section{1-1994}

\section{Evolution of the legal and market environment}

1991-1992 saw the first legislation concerned with real estate regulation. Amongst these were the first Privatisation Law (1991), the Law about Payment for Lands (1991), acts about the taxation of physical persons and business property (1991), the Law for Depths of Earth (1992), Stock Exchange regulations (1992), the first version of the Law about Bankruptcy (1992) and the Law about Insurance (1992). However, the necessary conceptual base for private property rights and their exchange and transfer were not formulated until later in 1993-1994 by the Russian Federation Constitution (December, 1993) and Part 1 of the Russian Federation Civil Code (October 1994). Only at the end of 1994 did the Civil Code include all the basic definitions of real estate and of jointstock companies, such as real estate structure, the definition of property rights, types of organisations, state registration, and privatisation. But the Civil Code's land property regulations (chapter 17) were conditional in character because of 
absence of a new Land Code. This was not approved until 2001. In 1994 the first property valuation standards were adopted and translated from those produced by the International Valuation Standards Committee by the Russian Society of Appraisers. They were advisory standards and were neither binding on valuers in general nor on members of the Russian Society of Appraisers. The commercial real estate market did not have any significant activity in any sector.

\section{Events and problems on the corporate and CREM front}

Presidential Orders (November 1992) set out the means of privatization for the state concerns in the fuel-energy sector. In practice, it opened opportunities and showed ways for the formation of large-scale joint-stock oil and gas companies. As a result in 1993 Gasprom (February) and LUKOIL (April) were established according to the Presidential Orders. The company YUCOS was formed (April 1993) as a union between the company Yuganskneftegas and three oilprocessing plants in Samara. The oil company Tatneft was registered in January 1993 after the privatization of the state concern of the same name. The formation of corporations ran ahead of the basic market legislation, including the Russian Federation Constitution and Civil Code.

The main characteristic of the period 1991-1994 was mass and rapid privatization. Speed and the quantity of privatizations were the leading criteria adopted for the success of the process. As a result, by the end of 1994, 112,000 undertakings had been privatized (approximately $75 \%$ of all active undertakings). The benefit to the state budget of income from the mass privatization for the period 1991-1994 was only \$300 million. There was not sufficient time in the demanding privatization timetable to describe in detail and properly appraise the privatized property objects, or to realise majority of the social objectives from the assets of privatized state monopolies. Economic results and the quality of privatized property management were not among the criteria for privatization given the need for the new businesses to secure markets and investment. The role of social and other non-profile assets of the new corporations and their CREM efficiency was not analysed and appraised in detail. In particular, the future of social assets, such as housing, schools, and hospitals, developed and managed by what were once state-owned industries and funded out of public budgets was not resolved, even though these corporate bodies were no longer part of the public sector. The problem of what to do about the land sites under the newly-privatized companies was not solved either, including the ownership rights. The result was latent real estate problems for the newly created corporations with their solution being delayed into the future.

\section{5-1996}

\section{Evolution of the legal and market environment}

Fundamental laws for corporate structure were approved, including laws about Natural Monopolies (1995), Finance-Industrial Groups (1995), and Joint-Stock 
Companies (1995). The second part of the Civil Code (1996) included norms for regulating all the main operations to do with real estate, such as buying and selling, renting, loans and credits, trust management, contracting, and alterations. A number of important laws for real estate and corporate management were passed, including the Water Code (1995) and the Law about Accountancy (1996). In particular, the accountancy norms defined rules for the valuation of real estate for corporate financial documents, audit, and taxation. The valuation base used was principally depreciated replacement cost but, at the same time, there was some limited opportunity to use market values as well. The Federal Law about confirmations for the division of products (1995) set out rules for foreign and Russian investments in nature resource extraction. The Law, together with the law about the depths of the earth (1992), created the fundamental legislative basis for regulation of mineral resource extraction and for the oil and gas industry in particular. By the end of 1996 a full set of International and European property valuation standards was translated and published by the Russian Society of Appraisers.

\section{Events and problems on the corporate and CREM front}

The most remarkable events were the first successes of corporations in the security markets. American Depository Receipts (ADR) of Tatneft were listed on the London Stock Exchange (1995). Shares in Gasprom were presented as ADR (1.1\% shares) in the stock exchanges of USA (1995), and in 1996 at the Federation Stock Exchange. LUKOIL's ADR started in 1996.

The legislative advances stimulated different corporative structures activities, in particular the rapid growth of finance-industrial groups. Their quantity grew to number forty by the end of 1996 and doubled in number during the next two years. The first experiences of a strategic partnership took place for LUKOIL with the American ARCO (1995) and for Gasprom with Shell (1996). The most significant state activity in the corporate sphere was the raising of funds by the Federal Government through loans backed by state-owned shares in the twelve most attractive industry concerns. The auctions were a variant of the privatisation process. According to the auction results, the state budget received nearly $\$ 700$ million. It was more than all the previous financial flows from privatisation activities. But the financial results were unsatisfactory compared with the real market values of the companies. As an example, the auction values of state share packets of oil companies were in the range of \$35-159 million (data from the weekly journal Commersant, N3, 1996).

1995-1996 did not bring any advances in CREM. The previously raised problems of real estate classification and actual databases, asset valuation, and social and non-profile assets continued though remained unrecognised in legislation. The corporate real estate database was absent and had no means of being filled and renewed (see blocks 6-9 of the Fig. 2). All the visible transfers, reorganisations and expansions for the growing corporations operated mainly in 
the corporate governance rather than real estate management sphere. The single most remarkable real estate development was in the form of a newly built central office for Gasprom in Moscow with a value of more than one billion dollars.

\section{7-1998}

\section{Evolution of the legal and market environment}

This was a period of intensive activity in real estate legislation. Amongst the new laws approved were the Law about State Registration of Real Estate Rights and Bargains with the Real Estate (1997), renewed laws for Privatization (1997) and Bankruptcy (1998), the Forest Code (1997), Town Planning Code (1998) and Part 1 of the Tax Code (1998), and laws about Non-State Pension Funds (1998), Valuation Activity (1998), Mortgages (1998), Licensing (1998), and Leasing (1998).

The state registration law at last opened normal ways for the real estate legal order and reliable corporate databases. The second versions of the privatization and bankruptcy laws reflected the active development of a market economy. The valuation law gave a foundation for market values in real estate bargains. The state as proprietor received a legal and methodical base for the appraisal of state property in privatization and other operations. The Town Planning Code continued the necessary principles for relations between society and owners, rules for real estate development, and the significance of planning. The licensing law included valuation activity as a licensed profession. The law about non-state pension funds gave a legal basis for future large-scale private real estate pension funds similar to the Western institutional investors. So, in spite of the financial crisis of 1998, the period saw the filling up of what had been empty spaces in the corporate and CREM legislative environment.

\section{Events and problems on the corporate and CREM front}

The financial crisis of August 1998 was a most dramatic event for the Russian economy and produced a harsh environment for corporations' activities. Nevertheless the second official version of the privatisation law (1997) and norms of the valuation activity law helped to create the new more efficient concept of cellular privatisation. Under this system, shares in major companies were sold in tranches rather than as single blocks, which could depress prices. As a result, plans for the cellular privatisation in 1997-1998 were calculated at $\$ 4,000$ million. State packets of shares in oil companies were valued at $\$ 200$ 600 million (data from the weekly journal Commersant, N31, 1997).

Tatneft developed its activity on stock exchanges in both Russia and abroad (as ADR on the New York Stock Exchange). Others, like LUKOIL, YUKOS, and Gasprom continued their policy of expansion and new strategic partnerships. These included expansions both in Russia and abroad. Amongst the strategic decisions it is important to note the domestic partnership between Gasprom and LUKOIL, alongside international alliances, such as Gasprom and ENI. Also 
Gasprom formed a joint-venture company for building the North-European gas pipeline. But the real estate component of the corporate expansions and collaborations continued to be in the shadows. The Law about state registration for real estate rights and bargains had opened but not yet stimulated corporations to concentrate their attention on the CREM sphere. In practice the description of real estate objectives was on the first step. An interesting structural management decision was the consolidation of LUKOIL subsidiary shares into the central company through equivalent exchanges of subsidiary and central company shares. It was one of the methods used to centralise and strengthen corporate top management, and at the same time to start the necessary real estate database formation.

In spite of the financial crisis of August 1998, the period saw the formation of the main legal mechanisms for the entry into the world economical space, opened opportunities to create, adapt, and confirm necessary standards, concepts, principles, and methods for professional services on markets, and the creation of perspectives for contemporary CREM. Data about the Moscow real estate market began to be published regularly in Western periodicals, such as EuroProperty. For the first time the problem of valuing state property and its peculiarities in transitional economies received attention in Western standards (Champness, 1997, n.5.10). Joint researches looked for ways for the efficient use and harmonisation of the different approaches to professional standards in real estate management (Grover et al., 1997).

\section{9-2000}

\section{Evolution of the legal and market environment}

This was a period of extreme depression and slow steps towards recovery. There was very little legislative development during the post-crisis period. The problem of a lack of investment was gradually solved with new laws about Investment Activity as Capital Investments (1999) and Foreign Investment (1999). It is remarkable that the laws were approved in a year in which the capital investment hit a trough with investment being only $60 \%$ of the level of 1994. Investment in 2000 reached $70 \%$ of the 1994 level, and only after 2002 was the 1994 investment level exceeded.

Part 2 of the Tax Code (2000) brought in a number of important norms for real estate taxation, such as types of taxes and the distribution between federal, regional, and municipal budgets. 2000 was also the year of the start of a series of land regulation laws including the Law about Land Cadastre (2000). In principle, it opened ways for proper CREM and reliable real estate database formation.

\section{Events and problems on the corporate and CREM front}

After the 1998 financial crisis, oil price growth stimulated corporate activities with the expansion of the fuel-energy corporations both in Russia and abroad. 
LUKOIL bought Getty Petroleum Marketing, including 1,300 petrol stations in 13 states of USA. YUKOS bought $68 \%$ of the shares of the East-Siberian oil-gas company. The LUKOIL-YUKOS-Gasprom Caspian Oil Consortium was created. The Tatneft bought a number of controlling shares of oil-production and oil-processing companies in Tatarstan.

The state (as the biggest proprietor and corporative co-proprietor) developed and articulated a new mission for federal real estate management, which has important implications for the way in which it is managed and the objectives to be achieved (1999). The state property strategy followed the state social and economical strategy. The majority of regional committees adopted similar missions and objectives. So the state proprietor made the first step to the modern model of the CREM similar to that in Figures 1 and 2.

However, in general, corporations' reactions to the financial crisis delayed necessary action to resolve CREM problems. Delay did nothing to make the real estate database creation and the social and non-profile assets problems more manageable, only more complex. It was already clear that the problem would be one of the most important in corporate management and real estate market development in the future.

\section{1 to the present time}

\section{Evolution of the legal and market environment}

The most remarkable legislative progress in the period was the approval of the Russian Federation Land Code (2001) and related land laws, such as the Law about Land Tenure Regulation (2001), Property Rights Delimitation for State Lands (2001), Agricultural Lands Turnover Regulations (2001), and Regulations for Altering Site Usage (2004). As a result, a definitive systematised legislative structure was created that includes previously approved Laws about Land Cadastre (2000), Payments for Land (1991), the corresponding norms of the Russian Federation Constitution (1993) and Civil Code (1994, 1996), the Town Planning Code (2004), Forest Code (1997) and Water Code (1995), the Law about the Depth of Earth (1992), and separate specialised norms from a number of other legislative documents, such as the Tax Code. The land problem finally received legislative regulation using market mechanisms. It had fundamental significance for CREM database formation. New versions of the Forest and Water Codes (2007) fixed Land Code priorities in real estate regulations.

Amongst other real estate laws were the Third Part of the Civil Code (2001, which is concerned mainly with inheritance regulations), the third version of the Privatisation Law (2001), the Law about Environment Protection (2002), the Law about the State and Municipal Utility Concerns (2002), the third version of the Law for Bankruptcy regulations (2002), and Law about Concessions (2005, which permitted the concession mechanisms for the state infrastructural objects). New versions of laws were needed to reflect the new demands of the reformed 
economic environment. For example, the new version of the bankruptcy regulation law corrected the mechanism for initiating bankruptcy. Since it was passed, the number of bankruptcy initiations has increased geometrically. Often bankruptcies were initiated without any objective reasons, but to serve speculative and dubious schemes for the property. The Corporate Code of Behaviour was published (2003) by the Federal Commission for Securities Market together with the Russian Institution of Corporative Directors.

\section{Events and problems on the corporate and CREM front}

The period after 2001 saw the step by step solution of many of the CREM problems. The period has seen stable corporate development, together with stable economic growth. The fuel-energy companies continued their advance in different security markets. The companies received investment rank and a stable place in the world lists of the biggest companies. Their capitalisation was at a compatible level with transcontinental giants. For example in 2003 the capitalisation of Gasprom was $\$ 28,150$ million, and in $2004-\$ 54,240$ million. The capitalisation of LUKOIL was in 2003 - \$15,520 million - and YUKOS $\$ 32,820$ million (data from the Russian analytical journal Expert, 2004).

The major fuel-energy companies continued to grow through acquisitions, structural reconstructions, and strategic unions in Russia and abroad. For example, the LUKOIL bought $75 \%$ of the shares of an oil-processing company in Serbia, and Gasprom and YUKOS made large acquisitions in Slovakia and Lithuania. There were a number of large-scale investment projects connected with pipeline construction by Gasprom, such as the Blue Flow to Turkey (20022003), and also the building of pipelines for Europe (through the Baltic Sea), and Asia pipeline plans with the China. The acquisitions, investment projects and plans were aimed at realising corporate strategy as a whole, but at the same time they produced more and more CREM problems. During the period a majority of large-scale corporations organised special CREM departments. Their tasks were to register corporate real estate and create detailed and transparent corporate databases. It was a start to a real advance in the way to a modern CREM as a corporate sub-system similar to that shown on the Figure 2. At last the specific formation function and corporate database filling and renewal (blocks 1, 6-9 of the Figure 2) received concrete meaning and execution.

The period showed increasing interest in strategic aspects of the corporations' development. LUKOIL approved a long-term programme in 2002 for its structural reorganisation and the optimisation of bore-holes. Gasprom approved a gas strategy for the period to 2010. Tatneft was a pioneer in specialised real estate management (2002). It had one of the first experiences of outsourcing amongst the large Russian corporations.

One of the principle aspects was the re-valuation of real estate assets according to open market principles. Tatneft re-valued its property assets (2001) in order to 
justify increasing the value of its capital fund. The revaluation would be an unremarkable procedure but for the results. The capital fund valuation was increased ten-fold, possibly reflecting an initial under-valuation of the assets of the corporation. It was important argument for using contemporary CREM concepts and principles. Because of its increasing significance, Tatneft committed the management of its subsidiaries' properties to an external company (2003). This was the next large-scale experience of outsourcing in Russia.

\section{A summary of 1991 to the present and CREM task integration}

The analysis of this starting period identified the following main sources of future real estate problems:

- disharmony between the processes of creating a real estate legislative base and the reform of market structures;

- gaps in the legislative base and the slow rate at which they were filled;

- decision making about corporation structures before the legislative base had been formulated and the CREM system created; and

- the accent on speed and numbers of privatizations ahead of the quality of the process.

The transitional period created a number of very serious problems that need to be solved for the corporations' further development and efficient CREM working. Developments transformed the starting characteristics (1)-(5) into the following.

(i) Corporate real estate database creation and its efficient use. Part of corporate real estate objects were included in the corporate assets during the start of privatisation (in 1991-1993) according to the privatization rules, but this was before the real estate registration law and valuation law were approved and implemented (1997-1998). There were also new objects built or purchased after privatisation but before the regulations of 1998 were passed. Finally, there were objects built or purchased after 1998 in accordance with contemporary demands. All these three categories of real estate objects form the integrated corporate database and could be used for corporate acts and bargains. Irrespective of the conditions under which they were acquired or developed, all real estate assets need to be included in the database and to be available to be used for different operations. In principle, clear understanding of management objectives opens the way to adopt and use modern principles of developed market economies, such as outsourcing, real estate partnerships, private financial initiative and public-private partnership, and sale and leaseback. Moreover global economical processes need clear and transparent asset rights. 
(ii) The future of corporate social real estate. During hasty privatizations it was very difficult to divide the built environment so that only commercial assets were privatized and to remove social and communal objects to regional or local authorities, together with responsibility for their maintenance. Corporate social policy can give a competitive advantage, for example, to encourage labour to reside in inhospitable areas by providing social benefits not found elsewhere. Thus, real estate objects have become a very important social problem to be solved through efficient interaction between the privatized companies and regional public authorities.

(iii) Corporate property asset optimisation. One of the most serious corporate real estate problems is connected with the so-called non-profile assets. Energy companies in particular have claims over the assets of other businesses and social bodies due to non-payment of utility bills. Whilst such claims are better than receiving no payment at all, they lead to imbalance in the corporate real estate structure and to additional difficulties in its property management. Those with claims are not able to exercise them or to convert them into assets of value to their core business. Thus the optimisation of the asset structure has become one of the most pressing tasks for corporate strategy a whole and the CREM strategy in particular.

\section{The steps for CREM creation: forming real estate objects for management}

CREM creation is a long-term and complicated process. It demands time and finances. The scale of the problem is more obvious for big corporations, like the aforementioned fuel-energy companies, such as Gasprom, with tens of thousands of real estate units, distributed throughout Russia as well as abroad. To summarise the tasks (i)-(iii): firstly it is necessary to provide strict legal, technical and financial order in corporate assets for their registration, the formation of quality CREM databases, unambiguous definitions of managed real estate objects, and their efficient use for the support of corporate strategic and operational activities, guarantees for necessary investments, providing for security markets transparency demands, and improving different corporate ranks.

In the context of the model (Figures 1 and 2), it means the concentration of efforts on block 1 "Forming real estate complexes for corporate tasks and problems solving". Why is block 1 the key-block for others and CREM as a whole? Different corporate tasks have different real estate requirements. For example, the creation of a new joint-venture company demands that a complete list of assets is included in the new company's capital. This in turn demands the corresponding alteration and renewal of the corporate real estate database. Another problem of corporate real estate structure optimisation mainly touches on the non-profile assets, but can demand the renovation of some concrete 
profile assets as well. Corporate management innovations will be connected with working space modernisation and the removal of personnel from the offices affected. Activities in the new markets can demand both new industrial and office assets, such as new gas pipelines and new representative offices in regions and towns. The corporate policy of total material resources must include all the business directions and corresponding assets. It demands the renewal of the whole real estate database. Any task and planned solution first of all needs a clean definition of the objects managed by CREM. Every change alters the assets, or partially alters them, causes them to operate with different parts of the general real estate database. So block 1 is a specific one and must be defined in detail. Other blocks are more traditional in their management context.

Figure 3 shows a structure for the formation of the real estate objects to be managed. The scheme develops and details the function shown in Figure 2 (block 1). In principle, the formation procedure includes the following main steps:

- exposing the object as a list of necessary assets;

- the identification of each real estate asset from the list with a detailed description; and

- standard presentation of the assets according to the demands of the corporate database and tasks to be solved.

There are lists and characteristics of corporate problems and tasks from the corporate strategic plans, programmes and other general documents (step 1.1 in Figure 3). Amongst the tasks are the problems (i)-(iii) as a consequence of the transition period and new tasks of corporate development, structural reforms, entrance into new regional markets, and so on. The real estate manager must follow the lists of problems and define the interconnection between the main corporate demands and corresponding sets of real estate objects. In the works of Soloviev \& Zakhartchenko $(2004,2005)$ the mechanism was defined as a matrix of correspondence between corporate tasks and real estate assets. The matrix helps to expose the necessary complexities of real estate assets for every task (step 1.2 in Figure 3). That is why the step is shown as a number of exposed complexes. For example, problem (i) means a total review and checking the corporate real estate. At the same time it requires sophistication to define an efficient structure for the database, its scale and details. This is important for all the future legal operations with the real estate. Problems (ii) and (iii) demand the identification of these real estate objects which must be, or can be, excluded from assets of the corporation, although some social objects can be useful for corporate internal social activities. Some non-profile units can be transferred to new subsidiary companies together with profile real estate objects. It requires logical combinations of assets for future legal transfers and registration. 
The next step (step 1.3 in Figure 3) is the identification of the characteristics of exposed objects. Information sources for the identification include different branch classifications and norms, technical documents, accounting balances, and reports. The classifications and norms can be elaborated and confirmed by special internal corporate standards and information bases. Here the Federal Law about the State Registration for the Real Estate Rights and Bargains with the Real Estate plays a positive role. The legal norms demand the determination of the legal, inventory, technical, and financial characteristics of each registered real estate object.

Figure 3.The CREM block 1 The formation of real estate complexes for solving corporate tasks and problems

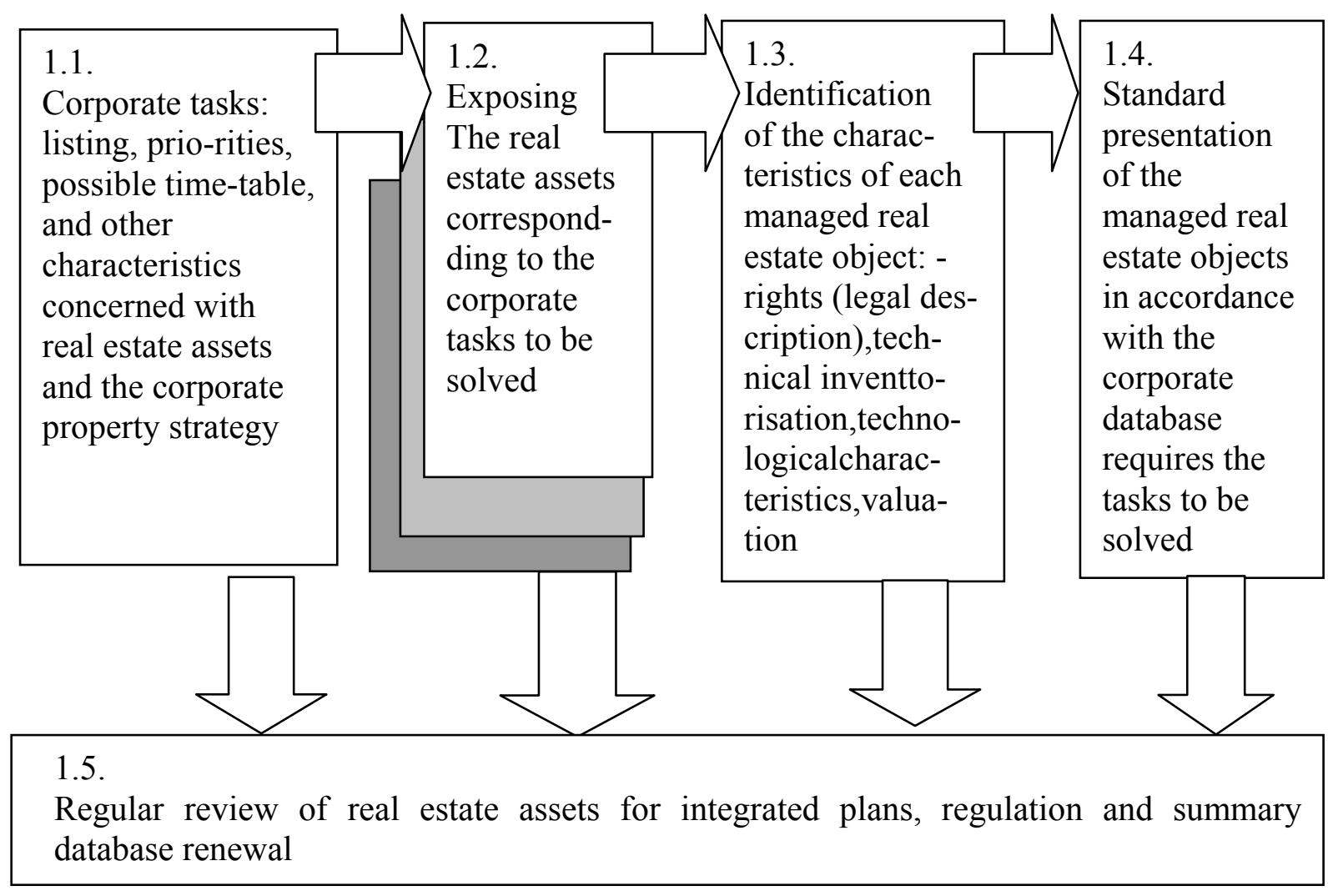

The importance of the getting the corporate real estate database right can be seen. The choice of the database units (for example, whether to take a gas pumping station as an entity or its technological elements) can influence the degree of complexity, the cost of the registration process, and flexibility and potential for future structural alterations. It requires highly professional work and costly expenditure for every registered object. The more detailed the technological objects the more expenditure on the registration process. The more technological complexes are combined the lower the registration expenditure. But fixed registration of big complexes decreases future flexibility and possible 
legal structure alteration. Future alteration will demand new details and registration procedures. The scale of corporate real estate objects is huge for the large-scale corporations like Gasprom, which has tens of thousands of real estate objects, costing some billions of dollars. This is why the registration process has proved to be rather expensive and to take so long, even once there is agreement on the property rights associated with each. Registration work for large-scale corporations is approximately half complete.

The standard presentation of real estate objects (step 1.4 in Figure 3) is defined by the demands of the corporate real estate database and the tasks to be solved. These demands are satisfied through modern information technologies. Wellorganised databases provide for transparency of corporate real estate assets. This is especially important for the unique and expensive real estate objects, such as drill holes and gas pipelines.

A principle role is played by step 1.5. Here real estate assets can be integrated for CREM planning and regulatory functions. It is important because parts of real estate assets will be included simultaneously into different activities. For example, some technological complexes can be planned for transfer to a new subsidiary company or joint venture and simultaneously be under a corporate policy of modernisation. Integration should lead to rational decision making and possible synergies.

\section{Conclusion}

1. The analysis shows that the mass rapid privatization, with its emphasis on the speed and quantity of privatizations, the general economic stagnation, the serious deficit of the formerly powerful centralised budget, the long-term negative gap of oil prices, and a strong desire to claim market position as soon as possible meant that the formation of large-scale fuel energy corporations was not systematic and thorough. A legislative base and strict norms for the formation of corporations and of real estate were absent at the start of the transition process. The base was filled very slowly and lagged behind the formation of market demands. Under the temporary regulations, the privatization of state property was at extremely under-valued prices. Thereupon postprivatization, the state share in the oil corporations swiftly decreased. The corporations had free opportunities for an efficient development. Their successes were marked by different kinds of recognition on the Western security markets. The corporations became leaders in the national securities market.

At that time having "approximate" real estate assets gave competitive advantages rather than being a burden for the corporate owners. Nevertheless the step-by-step completion of the market legislative base, the general stabilisation of economy, and serious intentions to be integrated into the world economy have forced both the corporations and the state to concentrate attention on real estate 
conditions and the problems to be solved. Corporate real estate, as the most critical and expensive asset, needs highly professional management. This is especially important for large-scale companies, such as fuel energy corporations. The presence or absence of a real estate department and the position of real estate managers in the company's top management can be a sign of how well a company has understood and solved the real estate problem. The real estate manager has to formulate critical tasks and understand their place in the corporate strategy, and ensure the readiness of the real estate to meet all the strategic, structural and operative acts for the achievement of corporate targets. So the contemporary CREM creation, development and use are among the most pressing corporate problems.

2. The model of the contemporary CREM presented here and recommended steps are based on the interconnection between corporate main purposes and tasks and CREM decision making. The steps include the consequences of exposure, identification and standard presentation of the real estate objects prepared for the management.

The complex character of the identification step (through the checking of property rights, detailed technical inventorisation, technological and safety control, and asset valuation) ensures the quality of the planned management and the regular renewal of the corporate database. Integration provides the CREM with efficient action and reliable feedback to the CMS main circle. Steps (1.1) (1.5) can help real estate managers provide an efficient start and development for their CREM subsystems in close contact with the strategic purposes and general tasks of corporations as a whole.

3. The transition from a centrally planned economy into a market one is a longterm process. It can be argued that it really only started in Russia in 1991, though the perestroika policy pursued by Gorbachev was a precursor. Its conclusion is difficult to define with any precision and depends upon the definition used. Politicians can argue that the transition period ends with a significant political act, such as the official recognition of a country as a market economy by the European Union or US State Department. Significant political events can help but not solve the majority of above-mentioned disharmonies and imbalances. Moreover politicians' time scales and their appraisals of results are influenced by election periods.

Investors may say that the transition finishes once there is reliable guarantees for investments and property rights that are not inferior to other parts of the commercial world. The same can be said for businessmen and their goods and services. The earlier the authorities can provide the guarantees and riskprotection, the earlier will the transition process be stabilised and the situation be similar to other developed economies. High investment rankings of some countries with transitional economies confirm the potential. 
What about corporations, corporate relations, and the CREM during the transition? The transition period's disharmony and imbalance are sources of serious external challenges to the corporations' successful development. The formation, completion, and stabilisation of the legal, economic, and social infrastructure are necessary conditions for successful corporate development. The management of corporations must make energetic steps to secure CREM creation and development. These include corporate real estate being registered, being capable of being valued, having clear property rights and financial transparency. The corporate real estate assets are becoming a real support to corporate strategies. At the same time the corporate real estate often includes unique constructions and equipment complexes, which can be critical for the social environment and ecology, and avoiding technology catastrophes. That is why society (and not only investors) is very sensitive to corporate real estate conditions.

\section{References}

Acoba, F./Foster, S. (2003): Aligning corporate real estate with evolving corporate missions: Process-based management models, in: Journal of Corporate Real Estate, 5, 2, 143164.

Allen, F./Gale, D. (2000): Bubbles and Crises, in: The Economic Journal, 110 (January), 236255.

Amaratunga, D. / Baldry, D. (1999): Building performance evaluation of higher education properties: towards a process model, in: Proceeding of COBRA 99 RICS (Construction and Building Research Conference), Salford, 2, 45-56.

Asson, T. (2002): Real estate partnerships: a new approach to corporate real estate outsourcing, in: Journal of Corporate Real Estate, 4, 4, 327-333.

Avis, M./Gibson, V. (1993): Property Management Performance Monitoring. Oxford Brookes and Reading Universities.

Bryan, B. (2003): The state of sale-leasebacks: What corporations can and should expect today, in: Journal of Corporate Real Estate, 6 (1), 15-23.

Champness, P. (1997): Approved European Property Valuation Standards. London, the Estate Gazette.

Cooke, H. (2004): FRS 12: Guidance on implementation for corporate real estate managers, in: Journal of Corporate Real Estate, 6, 4, 309-324.

Cotts, D. (1999): The Facility Management Handbook. American Management Association. Amacom. Translated and published in Russia (2001).

Crosby, N./Gibson, V./Oughton, M. (2001): Lease structures terms and lengths - a survey of corporate occupiers, in: RICS Cutting Edge Conference, Oxford.

Crosby, N. (2000): Valuation accuracy, variation and bias in the context of standards and expectations, in: Journal of Property Investment \& Finance, 18, 2, 130-161.

Devaney, S./Lizieri, C. (2004): Sale and leaseback, asset outsourcing and capital market impacts, in: Journal of Corporate Real Estate, 6, 2, 118-132. 
Gibson, V. (2000): Property portfolio dynamics: the flexible management of inflexible assets, in: Facilities, 18, 3/4, 150-154.

Grover, R.(ed.). (2000): Developing Real Estate Markets in Transition Economies. Paper for the UN Intergovernmental Conference, 6-8 December, Geneva.

Grover, R. (2006): European Union Accession and Land Tenure Data in Central and Eastern Europe, in: Land Reform, Land Settlement and Cooperatives, 2006/1.

Herring, R./Wachter, S (2002): Bubbles and Real Estate Markets, Paper prepared for the Federal Reserve Bank of Chicago and World Bank Group's Conference on Asset Price Bubbles: Implications for Monetary, Regulatory, and International Policies, Chicago, 22-24 April 2002.

Hill, M. (2001): Corporate Real Estate: Its Role in Maximising Shareholder Value, in: Journal of Corporate Real Estate, 3, 4, 335-345.

Ho, D.(ed.) (2000): Significant metrics for facilities management benchmarking in the Asia Pacific region, in: Facilities, 18, 13/14, 545-555.

Hudson, S./Wurtzebach, C. (1998): Managing Real Estate Portfolios, IRWN Professional Publishing. Translated and published in Russia (1998).

Joroff, M.(ed.) (1993): Strategic Management of the 5th Resource: Corporate Real Estate. IDRF.

Kaplan, R./Norton, D. (1996): The Balanced Score Card. Harvard Business School Press. Boston: MA.

Keeping, M./Shiers, D. (2003): Sustainable Property Development. Oxford: Blackwell Science.

Kincaid, D. (2000): Adaptability potentials for buildings and infrastructure in sustainable cities in: Facilities, 18, 3/4, 155-161.

Kops, D. (2003): Taking it to the next level: Corporate real estate becomes a business process, in: Journal of Corporate Real Estate, 6, 1, 24-29.

Lubieniecki, E./Desrocher, N. (2003): The case for simple comparison: A simple performance scorecard for effectiveness and efficiency, in: Journal of Corporate Real Estate, 6, 1, $39-52$.

Lyons, E. (2001): Toward global outsourcing: leveraging value for an international portfolio, in: Journal of Corporate Real Estate, 3, 4, 346-355.

McBlaine, R./Moritz, D. (2002): Transformational outsourcing: Delivering on the promise, in: Journal of Corporate Real Estate, 5, 1, 57-64.

McGregor, W. (2000): The future of workspace management, in: Facilities, 18, 3/4, 138-143.

McNamara, M. (2003): The future role of the property director, in: Journal of Corporate Real Estate, 4, 2, 57-64.

Msezane, T./McBride, J. (2002): Corporate real estate and business continuity: An integrated enterprise conceptualisation, in: Journal of Corporate Real Estate, 4, 4, 348-356.

Nutt, B. (2000): Four competing futures for facility management, in: Facilities, 18, 3/4, 124132. 
O’Mara, M. (1997): Corporate real estate strategy: uncertainty, values and decision making, in: Journal of Applied Real Property Analysis, 1, 1, 15-28.

O’Mara, M. (1999): Strategy and Place and Facilities for Competitive Advantage', New York: Simon and Shuster.

O'Mara, M.(ed.) (2002): The global corporate real estate function: Organisation, authority and influence, in: Journal of Corporate Real Estate, 4, 4, 334-347.

Osgood R. (2004): Translating organizational strategy into real estate action: The strategy alignment model, in: Journal of Corporate Real Estate, 2, 2, 106-117.

Pfnuer, A.(ed.) (2004): Aligning corporate real estate to real estate investment functions: Improved property decision making using a real option approach, in: Journal of Corporate Real Estate, 6, 3, 243-263.

Pfnuer, A./Armonat, S. (2003): German Corporate Property and the Conflict between Real Estate Investment and Operative Resources, in: Journal of Corporate Real Estate, 5, 4, 312-329.

Pomerleano, M. (2002): Back to the Basics: Critical Financial Sector Professions Required in the Aftermath of an Asset Bubble, in: The Appraisal Journal, April, 173-181.

Stoy, C./Kytzia, S. (2004): Strategies of corporate real estate management: Strategic dimensions and participants, in: Journal of Corporate Real Estate, 6, 4, 353-370.

Wagner, R.(ed.) (2003): SBC Communications' process for strategic and portfolio planning, in: Journal of Corporate Real Estate, 5, 2, 126-142.

Weatherhead, M. (1997): Real Estate in Corporate Strategy, Macmillan Press.

Yontz, W. (2001): Transformation of the real estate function into a corporate strategic business partner, in: Journal of Corporate Real Estate, 4, 1, 25-33.

Zappile, R. (2004): A quality process approach to corporate real estate management, in: Journal of Corporate Real Estate, 6, 3, 215-226.

*Grover, R./Soloviev, M. (2001): Real Estate Management, VSHPP, Moscow.

*Grover R./Soloviev, M. (1997): Introduction into Real Estate Management, Paritet, Moscow.

*Grabovy (ed.) (1999): Economy and Real Estate Management, MSBU, Moscow.

*Maximov, S. (2000): Business on the Real Estate Market, Piter, S-Petersburg.

*Maximov, S (2003): Real Estate Development, Piter, S-Petersburg.

*Soloviev, M./Zakhartchenko, V. (2004): Problems and Practice of Corporate Real Estate Management, in: Property Management, 1, 34-48.

*Soloviev, M./Zakhartchenko, V. (2005): Real Estate in Corporate Strategy, in: Property Management, 1, 34-48.

*The publications are in Russian language. 